\title{
How Can We Increase Shareholder' Wealth? An Empirical Validation from European Countries
}

\author{
Ben Said Hatem (Corresponding author) \\ Faculty of Law, Economics and Management of Jendouba \\ University of Jendouba, Jendouba, Tunisia \\ E-mail: hatmbensaid@gmail.com
}

Received: July 14, 2016 Accepted: April 5, 2017

doi:10.5296/ber.v7i1.9738 URL: https://doi.org/10.5296/ber.v7i1.9738

\begin{abstract}
This paper tests the determinants of shareholder's wealth. Our study examined three countries: Russia, Sweden and the United Kingdom. The samples contains 69 firms for every country observed over a period of 4 years from 2007 to 2010. Firm value is measured by two ratios: Tobin's $Q$ ratio obtained as the sum of market capitalisation, long term debt and short term capital structure divided by total assets, and market to book ratio measured as market value equity over shareholder's equity. The descriptive statistics manipulate that firms in Sweden and the United Kingdom have higher Tobin's Q and market to book ratios, respectively. We found evidence about the hypothesis of tax savings on firm value. Firms with higher values of performance have higher market equity values. We manipulated to a significant relationship between firm value and size when we consider, only Tobin's Q ratio, as dependant variable. More cash means high stocks prices for firms in Sweden and the United Kingdom. In the British and Swedish markets, older firms have less value.
\end{abstract}

Keywords: Firm value, Tobin's Q, Market to book, Shareholder's wealth, Market value equity

\section{Introduction}

Castagna and Matolcsy (1989) suggest that financial variables like sales, extraordinary items, tax and other incomes can affect firm value. Martikainen and Yli-Olli (1990) conclude that debt ratio is the most important factor in explaining firm value. Amihud's (2002) tests the factors identifying cumulative abnormal returns. Choe and Yang (2009) measure the effect of cash on stocks returns. Yun et al (2009) tests how sales can explain shareholder wealth. DeBondt and Thaler (1985), and Jegadeesh and Titman (1993) try to explain how firm characteristics such as firm size, market to book ratio can affect shareholders wealth. Cooper et al. (2008), Liu et al. (2009) and Cooper and Priestley (2011) conclude that stocks prices is 
a decreasing function of firm investment. We test the determinants of firm value. Specifically, we consider as a measure of shareholder wealth Tobin's Q and Market to Book ratios. Works that test the determinants of firm value are presented in next section. In Section 3, we introduce our sample, tested models and our variables. Section 4 manipulates the descriptive statistics and our empirical results. A sensitivity analysis of our specifications by sector is made in section 5. The last section presents with our main findings.

\section{The Literature Review}

Like Yli-Olli and Virtanen (1986), Teppo Martikainen (1992) tests the determinants of stock returns. The authors present the following variables; profitability, debt ratio, and growth opportunities. The authors argue that these variables affect stock prices, and therefore market value equity. They begin to calculate stock returns using the CAPM model. The empirical findings stimulate a positive interdependence between performance and share returns. However, the hypothesis of tax savings of debt is not checked. In fact, the authors conclude to a negative and a statistically significant interdependence between leverage and firm value.

In the line of works of Hager (1976), Kamath (1989), Soenen (1993), Jose et al. (1996), and Shin and Soenen (1998), Yung-Jang (2002) study the relationship between cash management and firm value. Examining a sample of 1555 companies from Japan and 379 Taiwanese firms over a period of 12 years from 1985 to 1996, the author found a minimum mean value of cash of 43 for the food sector and a maximum mean value of 89 for the service sector. To test the interdependence between cash management and firm value, Wang Yung-Jang (2002) conclude that for firms in Japan and Thailand with higher Q 1, have a lower liquidity value than other firms.

Similarly to Lewellen et al. (2010), Asparouhova, Bessembinder, and Kalcheva (2013), and Nagel (2013), Jaehoon, Yoon (2016) tested the factors explaining stocks returns. The authors identify determinants of stocks returns using the model proposed by Fama and MacBeth (1973). Testing a sample of firms from Korea for a period of 11 years from 1992 to 2002,the authors show to a negative and a statistically significant interdependence between share turnover and share price. Jaehoon, Yoon (2016) explain this conclusion by the effect of investor sentiment (Baker and Wurgler, 2006)

\section{Data and Methodology}

\subsection{Sample Selection}

To study the determinants of firm value, we test a sample of firms from three countries: Russia, Sweden and United Kingdom. Samples are extracted the from the "Amadeus » database and is described as follows: 69 companies from Russia, 69 firms from Sweden and 69 firms from United Kingdom. The unavailability of data of market capitalization, we consider a 4-year study period from 2007 to 2010.

\subsection{Choice of Variables and Hypothesis}

The dependent variable 
Firm value: according to the work of Demsetz and Villalonga (2001) and Hillier and McColgan (2001), shareholder wealth is measured alternatively by two ratios:

- Tobin's Q ratio approximated as the sum of market capitalization, long-term debt and short term capital structure divided by total assets (Lewellen and Badrinath, 1997; Aivazian et al., 2005; Rountree et al., 2008)

- Market to Book ratio calculated as the ratio of market capitalization divided by shareholders' equity.

The independent variables:

Leverage: Miller and Modigliani (1961) show the significant interdependence between debt ratio and corporate value. Like the work Georgeta and Stefan (2014), we estimate leverage as the ratio of total liabilities divided by total assets. Seunghyun Yoon, Jaemin, Seoki (2015) show that high debt ratios increase tax savings, and therefore firm value. However, with the increase of debt ratios, bankruptcy risk increases, which can negatively explain shareholder wealth. Hypothesis 1: debt affects positively or negatively firm value.

Profitability: according Miller (2004), Cheng (2008), Rountree et al (2008) and Nuryaman (2015), we estimate profitability by the ratio of net income divided by total assets. Profitability is a measure of firm performance. Therefore, the more firms are profitable, the greater shareholder wealth increases (Hirschey, 1982); Cockburn and Griliches, 1988; Morck, Shleifer, and Vishny, 1988; McConnell and Servaes, 1990), and Hall, 1993). Hypothesis 2: profitability positively affects shareholder wealth.

Firm size: similar to Cui and Mak, (2002), Connolly and Hirschey (2005), Rountree et al (2008), Cheng (2008), Levitas and Chi (2010) and Miller (2004), we estimate firm size by the logarithm of total assets. Agrawal Knoeber (1996) suggest for a negative interdependence between firm size and firm value. Indeed, for large firms, agency problems seem more severe. Therefore, shareholder wealth deteriorates. Furthermore, firms with higher size tend to be more diversified. However, Lang and Stulz (1994) suggest that diversification causes shareholder wealth destruction. Hypothesis 3: size negatively explains firm value.

Cash holdings: Like Yung-Jang Wang (2002), we measure cash by the ratio of cash and cash equivalents to total assets. High values of cash minimize bankruptcy risk, and increase, therefore, firm value. Hypothesis 4: cash holdings positively affect firm value.

Firm age: according to Cheng (2008), Ming-Yuan Chen (2013), we estimate corporate age as the number of years that separate the present date and the incorporation date. The oldest firms issue a good signal on their financial health, and thus firm value. Hypothesis 5: firm age positively explains firm value.

Table 1. Variables and expected signs

\begin{tabular}{|l|l|l|l|}
\hline Variables & Abbreviation & Formulation & Expected sign \\
\hline Tobin's Q & $\mathrm{Q}$ & (MVE+LTD+STD)/TA & Dependant Variable \\
\hline Market to Book & MTB & MVE/TA & Dependant Variable \\
\hline Leverage & DR & (LTD+STD) /TA & $+/-$ \\
\hline
\end{tabular}




\begin{tabular}{|l|l|l|l|}
\hline Profitability & ROA & Net income / TA & + \\
\hline Firms size & SIZE & Ln (TA) & - \\
\hline Cash holdings & CASH & Cash and Cash equivalents / TA & + \\
\hline Firm age & AGE & $\begin{array}{l}\text { Number of years between current } \\
\text { date and incorporation date. }\end{array}$ & + \\
\hline
\end{tabular}

\subsection{The Tested Models}

To identify the influence of our variables on shareholder's wealth, we manipulate the following models (McConnell and Servaes, 1990; Jensen, Solberg and Zorn,1992):

$$
\begin{aligned}
& Q_{i t}=\alpha_{0}+\alpha_{1} * D R_{i t}+\alpha_{2} * R O A_{i t}+\alpha_{3} * S I Z E_{i t}+\alpha_{4} * C A S H_{i t}+\alpha_{5} * A G E_{i t}+\varepsilon_{i t} \\
& M T B_{i t}=\beta_{0}+\beta_{1} * D R_{i t}+\beta_{2} * R O A_{i t}+\beta_{3} * S I Z E_{i t}+\beta_{4} * C A S H_{i t}+\beta_{5} * A G E_{i t}+v_{i t}
\end{aligned}
$$

\section{The Empirical Results}

\subsection{The Descriptive Statistics}

Our sample can be manipulated as follows (table 2). For Russia, the sample is distributed as follows. 20 industrial companies, 36 firms from the service sector, two firms in the real estate sector, 5 firms from the mining and agricultural sector, and 6 companies from Professional, scientific and technical activities. For Sweden, 7 industrial firms, 2 companies from the real estate sector, one firm from mining and agricultural sector and 59 firms in Professional, scientific and technical activities. Regarding United Kingdom, 42 companies of the service sector, 25 companies in the real estate sector and 2 agricultural firms. We can conclude from this distribution that most Russian and United Kingdom firms are from the service sector. However, for Sweden, most firms belong to the Professional sector.

Table 2. Distribution of our sample into activity sectors

\begin{tabular}{|l|l|l|l|l|l|l|}
\hline & Manufacturing & $\begin{array}{l}\text { Trade and } \\
\text { Service }\end{array}$ & Real estate & $\begin{array}{l}\text { Mining and } \\
\text { agriculture }\end{array}$ & $\begin{array}{l}\text { Professional. scientific } \\
\text { and technical activities }\end{array}$ & Total \\
\hline Russia & 20 & 36 & 2 & 5 & 6 & 69 firms \\
\hline Sweden & 7 & 0 & 2 & 1 & 59 & 69 firms \\
\hline $\begin{array}{l}\text { United } \\
\text { Kingdom }\end{array}$ & 0 & 42 & 25 & 2 & 0 & 69 firms \\
\hline
\end{tabular}

Table 3 highlight the descriptive statistics. The results show that shareholders' wealth measured by Tobin's Q ratio is higher for firms from Sweden with an average value of 1.567. However, when manipulating the Market To Book ratio, firms from United Kingdom are valued for an average of 3,472. Russian firms are the most profitable with an average profitability of 0.0669 and a minimum of -0.827 and a maximum of 0.529 . However, firms from Sweden are the most leveraged with an average debt ratio of 0.554 and are older with an average value of 47.601 years. Firms from United Kingdom have the higher size with an average of 20.918. However, William, Richard and Scott (2015) found an average size of 7,686 and 5,979 for high and low liquidity corporate. Moreover, these firms hold more cash with an average value of 0.114 . 
Table 3. Descriptive statistics

\begin{tabular}{|c|c|c|c|c|c|}
\hline & \multicolumn{4}{|c|}{ Russia } & \\
\hline & OBS & MEAN & STD DEV & MIN & MAX \\
\hline Q & 185 & 1,186 & 0,828 & 0,309 & 6,416 \\
\hline MTB & 184 & 1,699 & 2,667 & 0,00231 & 30,379 \\
\hline DR & 232 & 0,459 & 0,244 & 0,0330 & 0,999 \\
\hline ROA & 233 & 0,0669 & 0,127 & $-0,827$ & 0,529 \\
\hline SIZE & 233 & 20,834 & 1,891 & 14,501 & 26,147 \\
\hline CASH & 99 & 0,0688 & 0,0944 & 0,000028 & 0,695 \\
\hline \multirow[t]{3}{*}{ AGE } & 274 & 26,313 & 37,979 & 1 & 253 \\
\hline & \multicolumn{4}{|c|}{ Sweden } & \\
\hline & OBS & MEAN & \begin{tabular}{|l} 
STD DEV \\
\end{tabular} & MIN & MAX \\
\hline Q & 253 & 1,567 & 1,160 & 0,411 & 12,453 \\
\hline MTB & 251 & 2,791 & 4,898 & 0,154 & 56,977 \\
\hline DR & 263 & 0,554 & 0,148 & 0,102 & 0,956 \\
\hline ROA & 263 & 0,0570 & 0,0798 & $-0,436$ & 0,325 \\
\hline SIZE & 263 & 20,815 & 1,407 & 18,388 & 24,291 \\
\hline CASH & 263 & 0,0648 & 0,0641 & 0,000131 & 0,443 \\
\hline \multirow[t]{3}{*}{ AGE } & 276 & 47,601 & 35,409 & 2 & 113 \\
\hline & \multicolumn{4}{|c|}{ United Kingdom } & \\
\hline & OBS & MEAN & STD DEV & MIN & MAX \\
\hline $\mathrm{Q}$ & 255 & 1,405 & 0,761 & 0,455 & 5,731 \\
\hline MTB & 249 & 3,472 & 7,994 & 0,0707 & 82,760 \\
\hline DR & 256 & 0,548 & 0,164 & 0,112 & 0,983 \\
\hline ROA & 275 & 0,0552 & 0,116 & $-0,785$ & 0,649 \\
\hline SIZE & 270 & 20,918 & 1,516 & 17,529 & 24,673 \\
\hline CASH & 269 & 0,114 & 0,144 & 0,000253 & 0,824 \\
\hline AGE & 267 & 27,479 & 28,905 & 1 & 123 \\
\hline
\end{tabular}

\subsection{Determinants of Shareholder's Wealth}

The empirical findings on the factors explaining shareholder wealth are presented in the table 4 (Yli-Olli and Virtanen, 1985).

Table 4. Determinants of firm value

\begin{tabular}{|c|c|c|c|c|c|c|}
\hline & Russia & Russia & Sweden & Sweden & $\begin{array}{c}\text { United } \\
\text { Kingdom }\end{array}$ & $\begin{array}{c}\text { United } \\
\text { Kingdom }\end{array}$ \\
\hline & $\begin{array}{c}\text { Specification } \\
\mathbf{1}\end{array}$ & $\begin{array}{c}\text { Specification } \\
\mathbf{2}\end{array}$ & $\begin{array}{c}\text { Specification } \\
\mathbf{3}\end{array}$ & $\begin{array}{c}\text { Specification } \\
\mathbf{4}\end{array}$ & Specification 5 & Specification 6 \\
\hline & Tobin & MTB & Tobin & MTB & Tobin & MTB \\
\hline C & $-0,493$ & $-0,975$ & $0,931^{* *}$ & $-0,187$ & $2,386^{* * *}$ & 1,0600 \\
\hline DR & $0,922^{* * *}$ & $3,0915^{* * *}$ & 0,178 & $3,838^{* * *}$ & $0,292^{*}$ & $4,840^{* * *}$ \\
\hline ROA & $1,633^{* * *}$ & $3,716^{* *}$ & $3,992^{* * *}$ & $13,769^{* * *}$ & $0,825^{* * *}$ & $3,601^{* * *}$ \\
\hline SIZE & $0,059^{* *}$ & 0,0391 & $-0,00103$ & $-0,0433$ & $-0,0646^{* * *}$ & $-0,0525$ \\
\hline CASH & $-1,397^{* *}$ & $-0,918$ & $6,105^{* * *}$ & $9,657^{* * *}$ & $0,870^{* * *}$ & 1,112 \\
\hline AGE & $-0,000644$ & $-0,00299$ & $-0,00391^{* * *}$ & $-0,00271$ & $-0,00271^{* * *}$ & $-0,0158^{* * *}$ \\
\hline OBS & 62 & 62 & 253 & 251 & 242 & 233 \\
\hline R squared $(\%)$ & 34,49 & 12,74 & 260,83 & 133,87 & 77,71 & 110,26 \\
\hline Waldchi2 & 0 & 0,0259 & 0 & 0 & & 0 \\
\hline Prob> F & & & & & 0 \\
\hline
\end{tabular}

Note, ${ }^{* * *},{ }^{* * *}$ : significance at $10 \%, 5 \%$ and $1 \%$ levels respectively. 


\section{MInstitute ${ }^{\text {Mank }}$}

Leverage: as suggested by Bowman (1979), Christie (1982), Mandelker and Rhee (1984) and Bhandari (1988), an increase in the debt ratio leads to an enhance in shareholder wealth for firms in Russia. This conclusion is true for all specifications except for the Sweden, when we considered only the Tobin's Q ratio as an approximation of firm value. This conclusion corroborates our first hypothesis. Indeed, an increase in debt ratio is interpreted positively by external investors, which will positively explain firm value (Mandelker and Rhee, 1984; Blann and Balachandran, 1988). Jensen (1986) suggest that a higher debt ratio limits managerial discretion and, therefore, increases firm value

Profitability: a high profitability of firms in Russia, Sweden and the United Kingdom sends a good signal about the available growths opportunities. This explains the positive interdependence of our independent variable (Bowman, 1979; Kinnunen, 1988). This interpretation confirms our second hypothesis. An increase in performance implies a higher value of cash flows, and therefore, a higher firm value (Teppo Martikainen, 1992).

Firm size: the tested firm size hypothesis is verified, only for firms in the United Kingdom when we consider the Tobin's Q ratio as an approximation of shareholder wealth. However, the opposite effect is found in specification 1 for firms in Russia (William, Richard and Scott, 2015). Short and Keasey (1999) suggest that the largest firms could obtain external financing much easier and at a lower cost, which will increase firm performance and, consequently, firm value.

Cash holdings: high levels of cash are interpreted positively by the shareholders of firms in Sweden. This result is observed, also for specification 5 for firms in the United Kingdom. This interpretation confirms our hypothesis 4. However, a negative effect is recorded for specification 1 for Russia.

Firm age: the positive effect of firm age is not checked in our sample. We found a negative and a statistically significant effect for firms in the United Kingdom. This result is observed, also for specification 3 for firms in Sweden. This result can be highlighted as follows. The oldest firms have important agency problems, which will negatively explain firm value (Black, Jang, and Kim, 2006; Balasubramanian, Black, and Khanna, 2010).

\section{Determinants of Shareholder's Wealth and the Effect of Activity Sectors}

Similar to Barnhart and Rosentein (1998), we measure the impact of activity sectors on the determinants of shareholder wealth. We consider five activity sectors; The service sector, the real estate sector, the professionals activities, manufacturing and mining and agriculture activities (table 5). The empirical findings highlight that the income tax savings hypothesis of is not checked for two countries. Indeed, an increase in the debt ratio leads to a destruction of firm value for the industrial sector in Russia, and the real estate sector in Sweden. An increase in debt ratio implies to an increased bankruptcy risk, which will not increase firm value. However, the results of the real estate sector in the United King Dom, and professional activities in Sweden are positive and statistically significant. Inconsistent with our research hypothesis, increased profitability leads to a decrease in stock prices for the industrial sector in Russia, and the real estate sector in Sweden. Profitability positively influence firm value 
for the service sector in Russia, manufacturing and professional activities in Sweden, and the service and real estate sectors in the United King Dom. Contrary to the assumption of Lang and Stulz (1994), large size firms witness an increase in share prices for the manufacturing sector in Russia and the real estate sector in Sweden. However, the results on the United Kingdom become negative and statistically significant. High values of cash generate overinvestment problem, which will negatively explain shareholder wealth. This result is true in Sweden for the real estate sector. We found a positive effect of cash for the professional sector in Sweden, and the service sector in the United King Dom. Furthermore, older companies in the industrial and service sectors in Russia and the real estate and professional sectors in Sweden are the least valued. Indeed, these corporations have severe agency problems which will negatively explain firm value.

Table 5. Effects of activity sectors in explaining determinants of shareholder's wealth

\begin{tabular}{|c|c|c|c|c|c|}
\hline \multicolumn{6}{|c|}{ Russia } \\
\hline & Manufacturing & Service & Real estate & Mining & Professional \\
\hline & Tobin & Tobin & Tobin & Tobin & Tobin \\
\hline $\mathrm{C}$ & $-10,634^{*}$ & 0,421 & & & \\
\hline DR & $-3,823^{* * *}$ & 0,507 & & & \\
\hline $\mathrm{ROA}$ & $-3,297^{* *}$ & $1,452^{* *}$ & & & \\
\hline SIZE & $1,0888^{* * *}$ & 0,0246 & & & \\
\hline CASH & 0,422 & $-0,647$ & & & \\
\hline AGE & $-0,107^{* *}$ & $-0,0184^{*}$ & & & \\
\hline OBS & 23 & 33 & & & \\
\hline $\begin{array}{l}\mathrm{R} \quad \text { squared } \\
\text { Waldchi2 }\end{array}$ & 62,15 & 15,09 & & & \\
\hline Prob $>$ F & 0,0517 & 0,0100 & & & \\
\hline \multicolumn{6}{|c|}{ Sweden } \\
\hline & Manufacturing & Service & Real estate & Mining & Professional \\
\hline & Tobin & Tobin & Tobin & Tobin & Tobin \\
\hline $\mathrm{C}$ & $-1,851$ & & $-18,821^{* * * *}$ & & $0,722^{*}$ \\
\hline DR & 0,561 & & $-5,581^{* * *}$ & & $0,329^{* *}$ \\
\hline $\mathrm{ROA}$ & $4,593^{*}$ & & $-1,879^{* * *}$ & & $4,314^{* * *}$ \\
\hline SIZE & $-0,327$ & & $1,398^{* * *}$ & & 0,000783 \\
\hline $\mathrm{CASH}$ & 0,327 & & $-1,965^{* *}$ & & $7,388^{* * *}$ \\
\hline AGE & 0,127 & & $-0,0852^{* * *}$ & & $-0,00339^{* * * *}$ \\
\hline OBS & 27 & & 7 & & 216 \\
\hline $\begin{array}{r}\text { R squared (\%) } \\
\text { Waldchi2 } \\
\end{array}$ & 62,32 & & 99,84 & & 303,30 \\
\hline Prob $>F$ & 0,002692 & & 0,0278 & & 0 \\
\hline \multicolumn{6}{|c|}{ United Kingdom } \\
\hline & Manufacturing & Service & Real estate & Mining & Professional \\
\hline & Tobin & Tobin & Tobin & Tobin & Tobin \\
\hline $\mathrm{C}$ & & $1,875^{* *}$ & $5,562^{* * *}$ & 28,382 & \\
\hline DR & & $-0,525$ & $0,467^{* *}$ & 3,162 & \\
\hline $\mathrm{ROA}$ & & $1,312^{* * *}$ & $0,399^{* * *}$ & 7,406 & \\
\hline SIZE & & $-0,0190$ & $-0,221^{* * *}$ & $-1,425$ & \\
\hline $\mathrm{CASH}$ & & $1,744^{* * * *}$ & 0,0643 & 1,774 & \\
\hline AGE & & $-0,00161$ & 0,000150 & 0,0138 & \\
\hline OBS & & 139 & 95 & 8 & \\
\hline $\begin{array}{r}\text { R squared (\%) } \\
\text { Waldchi2 }\end{array}$ & & 25,94 & 64,16 & 87,23 & \\
\hline
\end{tabular}


Note $,{ }^{* * * * * *},{ }^{* *}$ significance at $10 \%, 5 \%$ and $1 \%$ levels respectively.

\section{Conclusion}

Our paper test how managers can increase shareholder's wealth (Harvey, 1995; Dicle et al., 2010; Hjalmarsson, 2010; Gupta and Modise, 2012; Narayan and Bannigidadmath, 2015; Narayan et al., 2015b; Westerlund et al., 2015; Fama and French, 1988; Lamont, 1998; Welch and Goyal, 2008; Rapach et al., 2010 and Gupta et al., 2014). We measure firm value by Tobin's Q and market to book ratios. The empirical findings of the determinants of firm value show that leverage positively affects firm value. In general, our results present that managers can take decisions to increase stock prices and, consequently, shareholder's wealth. The effect of profitability is positive and statistically significant. The effect of firm size is contradictory. We found a positive effect for firms in Russia, and a negative effect for firms in the United Kingdom. Cash positively explains firm value in Sweden and the United King Dom (specification 5). Only, for Sweden ( specification 3) and the United Kingdom, we have found that older firms have lower Tobin's $Q$ values and market to book ratios. Furthermore, we found that our results are sensitive to activity sector (the service sector, the real estate sector, professionals, manufacturing and mining and agricultural activities). The results present that an increase in debt ratio increase shareholder's wealth for professional activity in Sweden, and the real estate sector in the United King Dom. A positive effect of profitability was found for the service sector in Russia, manufacturing and professional activities for firms in Sweden and the service and real estate sectors in the United Kingdom. Firm size negatively explain firm value for the real estate sector for firms in the United Kingdom. More cash means an increase in shareholder's wealth for the service sector firms from United Kingdom and professional activities for firms in Sweden. Overall, older firms have lower stock prices.

\section{References}

Agrawal, Xinier Zhao. (2007). The Leverage-Value Relationship Puzzle: An Industry Effects Resolution, Journal of Economics and Business, 59(4), 286.

https://doi.org/10.1016/j.jeconbus.2006.07.001

Aivazian, V. A., Ge, Y., \& Qiu, J., (2005). The impact of leverage on firm investment: Canadian evidence. Journal of Corporate Finance, 11(1-2), 277-291.

https://doi.org/10.1016/S0929-1199(03)00062-2

Amihud, Y., (2002). Illiquidity and stock returns: cross-section and time-series effects. Journal of Financial. Markets, 5, 31-56. https://doi.org/10.1016/S1386-4181(01)00024-6

Asparouhova, E., Bessembinder, H., \& Kalcheva, I., (2013). Noisy prices and inference regarding returns. Journal of Finance, 68, 665-714. https://doi.org/10.1111/jofi.12010

Baker, M., \& Wurgler, J., (2006). Investor sentiment and the cross-section of stock returns. Journal of Finance, 61, 1645-1680. https://doi.org/10.1111/j.1540-6261.2006.00885.x

Balasubramanian, N., Black, B. S., \& Khanna, V., (2010). The relation between firm-level 
corporate governance and market value: A case study of India, Emerging Markets Review, 11(4), 319-340. https://doi.org/10.1016/j.ememar.2010.05.001

Barnhart, S. W., \& Rosenstein, S, (1998). Board Composition, Managerial Ownership, and Firm Performance: An Empirical Analysis, Financial Review, 33(4), 1-16.

https://doi.org/10.1111/j.1540-6288.1998.tb01393.x

Bhandari, L. C. (1988). Debt/equity ratio and expected common stock returns: empirical evidence, Journal of Finance, 2, 507-528.

https://doi.org/10.1111/j.1540-6261.1988.tb03952.x

Black, B., Jang, H., \& Kim, W., (2006). Does corporate governance affect firm value? Evidence from Korea, The Journal of Law, Economics, \& Organization, 22(2), 366-413. https://doi.org/10.1093/jleo/ewj018

Blann, J., \& Balachandran, B. V. (1988). An empirical test of the statistical association between market risk and financial accounting allocation, Journal of Business Finance and Accounting, 1, 101-113.

Bowman, R. G. (1979). The theoretical relationship between systematic risk and financial (accounting) variables, Journal of Finance, 3, 617-630.

https://doi.org/10.1111/j.1540-6261.1979.tb02129.x

Castagna, A. A., \& Matolcsy, Z. P. (1989). The marginal information content of selected items in financial statements, Journal of Business Finance and Accounting, 3, 317-333. https://doi.org/10.1111/j.1468-5957.1989.tb00021.x

Cheng, S., (2008). Board size and the variability of corporate performance. Journal of Financial. Economics, 87(1), 157-176. https://doi.org/10.1016/j.jfineco.2006.10.006

Choe, H., \& Yang, C. W. (2009). Liquidity risk and asset returns: the case of the Korean stock market. Kor. Journal of Financ, 26e, 103-140.

Christie, A. A., (1982). The stochastic behaviour of common stock variances: value, leverage and interest rate effects, Journal of Financial Economics, 4, 407-432.

https://doi.org/10.1016/0304-405X(82)90018-6

Cockburn, I., \& Griliches, Z. May (1988). Industry effects and appropriability measures in the Stock Market's valuation of R\&D and patents. American Economic Review, 78, 419-423.

Connolly, R. A., \& Hirschey, M., (2005). Firm size and the effect of R\&D on Tobin's q. $R \& D$ Management, 35(2), 217-223. https://doi.org/10.1111/j.1467-9310.2005.00384.x

Cooper, M. J., Gulen, H., \& Schill, M. J., (2008). Asset growth and the cross-section of stock returns. Journal of Finance, 63, 1609-1651.

https://doi.org/10.1111/j.1540-6261.2008.01370.x

Cooper, I., \& Priestley, R., (2011). Real investment and risk dynamics. Journal of Financial. Economics, 101, 182-205. https://doi.org/10.1016/j.jfineco.2011.02.002 


\section{Ml Macrothink}

Business and Economic Research ISSN 2162-4860 2017, Vol. 7, No. 1

Cui, H. M., \& Mak, Y. T., (2002). The relationship between managerial ownership and firm performance in high R\&D firms. Journal of Corporate Finance, 8(4), 313-336.

https://doi.org/10.1016/S0929-1199(01)00047-5

DeBondt, W. F. M., \& Thaler, R., (1985). Does the stock market overreact? Journal of Finance, 40, 793-805. https://doi.org/10.1111/j.1540-6261.1985.tb05004.x

Demsetz, H., \& Villalonga, B. (2001). Ownership structure and corporate performance. Journal of Corporate Finance, 7, 209 - 233. https://doi.org/10.1016/S0929-1199(01)00020-7

Dicle, M., Beyhan, A., \& Yao, L., (2010). Market efficiency and international diversification: evidence from India. International Review of Economics and. Finance, 19, 313-339. https://doi.org/10.1016/j.iref.2009.09.003

Fama, E. F., \& French, K. R., (1988). Dividend yields and expected stock returns. Journal of Financial Economics, 22, 3-25. https://doi.org/10.1016/0304-405X(88)90020-7

Fama, E. F., \& MacBeth, J., (1973). Risk, return, and equilibrium: empirical tests. Journal of Political Economy, 71, 607-636. https://doi.org/10.1086/260061

Georgeta Vintila, Stefan Cristian Gherghina. (2014). The impact of ownership concentration on firm value. Empirical study of the Bucharest Stock Exchange listed companies, Procedia Economics and Finance, 15, 271-279. https://doi.org/10.1016/S2212-5671(14)00500-0

Gupta, R., Hammoudeh, S., Modise, M. P., \& Nguyen, D. K., (2014). Can economic uncertainty, financial stress and consumer sentiments predict US equity premium? Journal of International Financial Markets, Institutions and Money, 33, 367-378.

https://doi.org/10.1016/j.intfin.2014.09.004

Gupta, R., \& Modise, M. P., (2012). South African stock return predictability in the context data mining: the role of financial variables and international stock returns. Economic Modelling, 29, 908-916. https://doi.org/10.1016/j.econmod.2011.12.013

Hager, H. C., (1976). Cash management and the cash cycle. Management Accounting, 57, 19-21.

Hall, B. May (1993). The Stock Market's valuation of R\&D investment during the 1980's. American Economic Review, 83, 259-264.

Harvey, C. R., (1995). Predictable risk and returns in emerging markets. Review of Financial Studies, 8, 773-816. https://doi.org/10.1093/rfs/8.3.773

Hillier, D., \& McColgan, P. (2001). Insider ownership and corporate value: An empirical test from the United Kingdom corporate sector. Paper presented at the Financial Management Association (FMA) Meeting, Paris.

Hirschey, M. June (1982). Intangible capital aspects of advertising and R\&D expenditures. Journal of Industrial Economics, 30(4), 375-391. https://doi.org/10.2307/2097924

Hjalmarsson, E., (2010). Predicting global stock returns. Journal of Financial and 
Quantitative analysis, 45, 49-80. https://doi.org/10.1017/S0022109009990469

Jaehoon Hahn, \& Heebin Yoon. (2016). Determinants of the cross-sectional stock returns in Korea: evaluating recent empirical evidence, Pacific-Basin Finance Journal, 38, 88-106. https://doi.org/10.1016/j.pacfin.2016.03.006

Jegadeesh, N., \& Titman, S., (1993). Returns to buying winners and selling losers: implications for stock market efficiency. Journal of Finance, 48, 65-91. https://doi.org/10.1111/j.1540-6261.1993.tb04702.x

Jensen, M. C. (1986). Agency costs of free cash flow, corporate finance, and takeovers. American Economic Review, 76(2), 323-329.

Jensen, G., Solberg, D., \& Zorn, T. June (1992). Simultaneous determination of insider ownership, debt, and dividend policies. Journal of Financial and Quantitative Analysis, 27(2), 247-263. https://doi.org/10.2307/2331370

Jose, M. L., Lancaster, C., \& Stevens, J. L., (1996). Corporate returns and cash conversion cycles. Journal of Economics and Finance, 20, 33-46. https://doi.org/10.1007/BF02920497

Kamath, R., (1989). How useful are common liquidity measures? Journal of Cash Management, 9, 24-28

Kinnunen, J. The time series properties of accrual versus cash-based income variables: empirical evidence from listed Finnish firms. Proceedings of the Helsinki School of Economics, A-58.

Lamont, O., (1998). Earnings and expected returns. Journal of Finance, 53, 1563-1587. https://doi.org/10.1111/0022-1082.00065

Lang, L., \& Stulz, R. (1994). Tobin's q, corporate diversification, and firm performance. Journal of Political Economy, 102(6), 1248-1280. https://doi.org/10.1086/261970

Levitas, E., \& Chi, T., (2010). A look at the value creation effects of patenting and capital investment through a real options lens: the moderating role of uncertainty. Strategic Entrepreneurship Journal, 4(3), 212-233. https://doi.org/10.1002/sej.92

Lewellen, W. G., \& Badrinath, S. G., (1997). On the measurement of Tobin's q. Journal of Financial Economics, 44(1), 77-122. https://doi.org/10.1016/S0304-405X(96)00013-X

Lewellen, J., Nagel, S., \& Shanken, J., (2010). A skeptical appraisal of asset pricing tests. Journal of Financial. Economics, 96, 175-194. https://doi.org/10.1016/j.jfineco.2009.09.001

Li-Olli, P., \& Virtanen, I. (1986). On the stability of the classification of financial ratios. An application of factor and transformation analysis. Proceedings of the University of Vaasa Research Papers, 117.

Mandelker, G. N., \& Rhee, S. G., (1984). The impact of the degrees of operating and financial leverage on systematic risk of common stock, Journal of Financial and Quantitative Analysis, 1, 45-57. https://doi.org/10.2307/2331000 
Martikainen, T., \& Yli-Olli, P. (1990). A test of the arbitrage pricing theory using accounting information, Economics Letters, 1, 55-59. https://doi.org/10.1016/0165-1765(90)90181-Y

McConnell, J., \& Servaes, H. (1990). Additional evidence on equity ownership and corporate value. Journal of Financial Economics, 27(2), 595-612.

https://doi.org/10.1016/0304-405X(90)90069-C

Miller, D. J. (2004). Firms technological resources and the performance effects of diversification: a longitudinal study. Strategic Management Journal, 25(11), 1097-1119. https://doi.org/10.1002/smj.411

Miller, M. H., \& Modigliani, F. (1961). Dividend policy, growth and the valuation of shares, Journal of Business, 4, 411433. https://doi.org/10.1086/294442

Ming-Yuan Chen, (2013). Adjustments in managerial ownership and changes in firm value, International Review of Economics and Finance, 25, 1-12.

https://doi.org/10.1016/j.iref.2012.04.008

Morck, R., Shleifer, A., \& Vishny, W. (1988). Management ownership and market valuation: An empirical analysis. Journal of Financial Economics, 20(1/2), 293-316.

https://doi.org/10.1016/0304-405X(88)90048-7

Nagel, S. (2013). Empirical cross-sectional asset pricing. Annual Review of Financial Economics, 5, 167-199. https://doi.org/10.1146/annurev-financial-110112-121009

Narayan, P. K., \& Bannigidadmath, D. (2015). Are Indian stock returns predictable? Journal of Banking and Finance, 58, 506-531. https://doi.org/10.1016/j.jbankfin.2015.05.001

Narayan, P. K., \& Sharma, S. (2015b). Is carbon emissions trading profitable? Economic Modelling, 47, 84-92. https://doi.org/10.1016/j.econmod.2015.01.001

Nuryaman, (2015). The Influence of Intellectual Capital on The Firm's Value with The Financial Performance as Intervening Variable. Procedia - Social and Behavioral Sciences, 211(25), 292-298. https://doi.org/10.1016/j.sbspro.2015.11.037

Rapach, D. E., Strauss, J. K., \& Zhou, G., (2010). Out-of-sample equity premium prediction: combination forecasts and links to the real economy. Review of Financial Studies, 23, 821-862. https://doi.org/10.1093/rfs/hhp063

Rountree, B., Weston, J. P., \& Allayannis, G., (2008). Do investors value smooth performance? Journal of Financial Economics, 90(3), 237-251.

https://doi.org/10.1016/j.jfineco.2008.02.002

Seunghyun Kima, Yoon Kohb, Jaemin Chaa, Seoki Leec. (2015). Effects of social media on firm value for U.S. restaurant companies. International Journal of Hospitality Management, 49, 40-46. https://doi.org/10.1016/j.ijhm.2015.05.006

Shin, H. H., \& Soenen, L. (1998). Efficiency of working capital management and corporate profitability. Financial Practice and Education, 37-45. 


\section{Macrothink}

Business and Economic Research ISSN 2162-4860 2017, Vol. 7, No. 1

Short, H., \& Keasey, K., (1999). Managerial ownership and the performance of firms: Evidence from the UK, Journal of Corporate Finance, 5(1), 79-101.

https://doi.org/10.1016/S0929-1199(98)00016-9

Soenen, L. A., (1993). Cash conversion cycle and corporate profitability. Journal of Cash Management, 13, 53-57.

Teppo Martikainen. (1992). On the maximization of shareholders' wealth: evidence based on firm-specific financial characteristics, Scandinavian Journal of Management, 8(1), 15-33, 1992. https://doi.org/10.1016/0956-5221(92)90004-X

Welch, I., \& Goyal, A., (2008). A comprehensive look at the empirical performance of equity premium prediction. Review of Financial Studies, 21, 1455-1508.

https://doi.org/10.1093/rfs/hhm014

Westerlund, J., \& Narayan, P., (2015). Testing for predictability in conditionally heteroskedastic stock returns. Journal of Financial. Economics, 13, 342-375.

https://doi.org/10.1093/jjfinec/nbu001

William Mingyan Cheung, Richard Chung, \& Scott Fung. (2015). The effects of stock liquidity on firm value and corporate governance: Endogeneity and the REIT experiment, Journal of Corporate Finance, 35, 211-231. https://doi.org/10.1016/j.jcorpfin.2015.09.001

Yli-Olli, P., \& Virtanen, I. (1985). Modelling a financial ratio system on the economy-wide level. Proceedings of the University of Vaasa, Acta Wasaensia, 21.

Yung-Jang Wang. (2002). Liquidity management, operating performance, and corporate value: evidence from Japan and Taiwan, Journal of Multinational Financial Management, 12, 159-169. ttps://doi.org/10.1016/S1042-444X(01)00047-0

Yun, S. Y., Ku, B., Eom, Y. H., \& Hahn, J., (2009). The cross-section of stock returns in Korea: an empirical investigation. Asian Rev. Financ Res. 22, 1-43.

Yli-Olli, P., \& Virtanen, I., (1986). On the stability of the classification of financial ratios. An application of factor and transformation analysis. Proceedings of the University of Vaasa. Research Papers, 117.

\section{Copyright Disclaimer}

Copyright for this article is retained by the author(s), with first publication rights granted to the journal.

This is an open-access article distributed under the terms and conditions of the Creative Commons Attribution license (http://creativecommons.org/licenses/by/3.0/). 